$$
\begin{aligned}
\text { DOE } / B C / 14984-11 \\
B C / 14984-11
\end{aligned}
$$

\title{
IMPROVED RECOVERY DEMONSTRATION FOR WILLISTON BASIN CARBONATES
}

\author{
QUARTERLY TECHNICAL PROGRESS REPORT
}

Cooperative Agreement DE-FC22-94BC14984
Luff Exploration Company
Denver, Colorado

Award Date: June 10, 1994

Completion Date: December 31, 1997

Government Award: \$1,778,014

APSOTHAT

Project Manager:

Larry A. Carrell

Luff Exploration Company

DOE Project Officer:

Chandra Nautiyal

Bartlesville Project Office

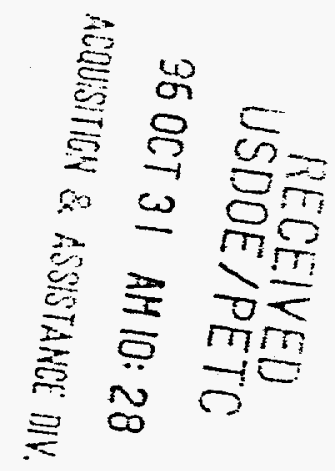

Reporting Period: July through September 30, 1996

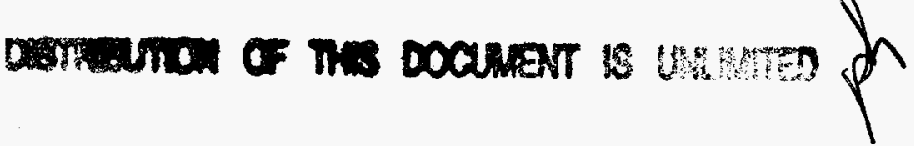

U.S. DOE Patent Clearance is not required prior to the publication of this document

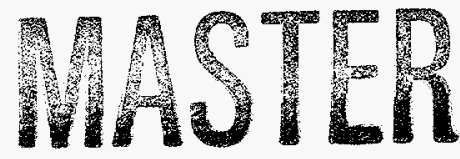




\section{DISCLAIMER}

This report was prepared as an account of work sponsored by an agency of the United States Government. Neither the United States Government nor any agency thereof, nor any of their employees, make any warranty, express or implied, or assumes any legal liability or responsibility for the accuracy, completeness, or usefulness of any information, apparatus, product, or process disclosed, or represents that its use would not infringe privately owned rights. Reference herein to any specific commercial product, process, or service by trade name, trademark, manufacturer, or otherwise does not necessarily constitute or imply its endorsement, recommendation, or favoring by the United States Government or any agency thereof. The views and opinions of authors expressed herein do not necessarily state or reflect those of the United States Government or any agency thereof. 


\section{DISCLAMMER}

Portions of this document may be illegible in electronic image products. Images are produced from the best available original document. 


\section{MMPROVED RECOVERY DEMONSTRATION FOR WILLISTON BASIN CARBONATES}

Contract No. DE-FC22-94BC14984

Luff Exploration Company

Denver, Colorado

Contract Date: June 10, 1994

Anticipated Completion: December 31, 1997

Government Award: \$1,778,014

Principal Investigators:

Mark A. Sippel

Larry A. Carrell

Project Manager:

Chandra Nautiyal

Bartlesville Project Office

Reporting Period: July 1 - Sept. 30, 1996

\section{Objectives}

The purpose of this project is to demonstrate targeted infill and extension drilling opportunities, better determinations of oil-in-place, methods for improved completion efficiency and the suitability of waterflooding in certain shallow-shelf carbonate reservoirs in the Williston Basin, Montana, North Dakota and South Dakota.

Improved reservoir characterization utilizing 3-dimensional (3D) and multi-component seismic are being investigated for identification of structural and stratigraphic reservoir compartments. These seismic characterization tools are integrated with geological and engineering studies. Improved completion efficiency is being tested with short-lateral and horizontal drilling technologies. Improved completion efficiency, additional wells at closer spacing and better estimates of oil-in-place will result in additional oil production by primary and enhanced recovery processes.

\section{Summary of Technical Progress}

Ractliffe Core Analysis

An oriented core (10.2 cm, 4 inch diameter) was obtained through the Ratcliffe interval ( 2676.9 to $2703.1 \mathrm{~m}, 8783$ to $8869 \mathrm{ft}$ ) at the Federal 1-17 R, North Sioux Pass Field (see Fig. 1 for location of well). A Sclumberger Formation Micro Imaging (FMI) log was also run across the interval. Several fractures were observed in the core. Core Lab ran fracture analysis of the core and established an orientation for the fractures. The FMI log was able to image the fractures which are observed in the core and produced a fracture orientation similar to the work performed by Core Lab. Conventional porosity-permeability studies were done with special core studies for wettability, capillary pressure and oil-water relative permeability. Evaluation of the electrical logs indicate a productive thickness of $4.6 \mathrm{~m}$ (15 $\mathrm{ft}$ ), average porosity of $8.8 \%$ and water saturation of $46 \%$. The majority of the productive rock is in a $2.1 \mathrm{~m}(7 \mathrm{ft})$ interval at $2684 \mathrm{~m}(8806 \mathrm{ft})$. Core porosity of this interval averages $12.9 \%$ with a geometric-mean permeability of $4.9 \mathrm{E}-4 \mu \mathrm{m}^{2}(0.5$ md) and maximum permeability of $1.3 \mathrm{E}-3 \mu \mathrm{m}^{2}$ $(1.3 \mathrm{md})$. See figure 2 for porosity $\log$ and core interval of the Ratcliffe in the Federal 1-17R well.

The core was slabbed for petrographical analysis which is in-progress by Mike Hendricks and Asscociates. The core has been photographed and several thin sections were also obtained.

\section{Ratcliffe Re-Entry Lateral Completions}

Two wells in the North Sioux Pass Field have been selected for re-entry lateral completion in the Ratcliffe. These wells are the M-17 Trudell and 216 State (Fig. 1). The laterals will be drilled out from $14 \mathrm{~cm}$ (5-1/2 inch) casing with steeredmotor technology with planned extensions of 610 $\mathrm{m}(2000 \mathrm{ft})$. Orientation of the laterals will be normal to the fracture orientation observed from the 1-17R Federal core and FMI log data. The reentry lateral drilling activity has been delayed because of limited availability of special tubulars for the work string. These tubulars are now available and the work is scheduled to commence on about November 1. 
Red River Targeted Drilling

Drilling operations are underway at the B-27 State-Muslow well in Bowman Co., ND (Fig. 3). The vertical well was targeted from a $3 \mathrm{D}$ seismic survey over Cold Turkey Creek Field. The well is expected to be at total depth by November 1 . Contiguous cores will be cut across the entire upper Red River section $(64 \mathrm{~m}, 210 \mathrm{ft})$. These cores will cover all four porosity benches (A, B, C and $D$ zones) in the Red River. Sonic and density logs will be obtained for further syntheticseismogram study and evaluation of the $3 D$ seismic survey.

Luff Exploration Company participated in drilling a horizontal completion in the Red River B zone reservoir at State Line Field, Bowman Co., ND (Fig. 4). The 1-26H Greni well is the fourth well on a small Red River feature. The well is completed as a producer and will provide important production data for the evaluation of incremental reserves through horizontal completions from older fields which were previously depleted by vertical wells.

\section{Red River Lateral Drilling}

Drilling operations for a horizontal injection well at Buffalo Field (North Area) will commence in November after completion of the B-27 StateMuslow well. The Red River B zone is the target of the horizontal completion at the M-20H Stearns well (Fig 5.). The Red River B zone will be logged and drillstem tested through a vertical hole. The well will then be plugged-back and the horizontal section drilled. The state of South Dakota has approved a four-week water injection test. The lateral extension is planned to be 1219 $\mathrm{m}(4000 \mathrm{ft})$ and will be between two existing vertical wells. The success of the water-injectivity test will be an important step toward unitization and developing a field-wide waterflood project. The project has obtained water injectivity data and pressure buildup data from nearby wells. These hard data will be used in construction of computer simulation models for projected waterflood recovery with horizontal completions.
Red River Geophysical

A 3D seismic survey was acquired over Grand River School Field in Bowman Co., ND (Fig. 3). Data processing is completed. Interpretation work is integrating the new data with the nearby Cold Turkey Creek 3D survey and waiting on the new sonic and density $\log$ to be obtained at the B-27 State-Muslow (Cold Turkey Creek) well. Re-processed 2D seismic data are being integrated into both the Cold Turkey Creek and Grand River School 3D surveys.

Ratcliffe Geophysical

A 3D seismic survey is underway at North Sioux Pass Field, Richland Co., MT (Fig. 1). Seismic evaluations of the Ratcliffe from this survey will be included as part of the Ratcliffe reservoir characterizations for the project.

Summary and Conclusions

Field demonstrations are in progress to collect data for evaluation of horizontal completions in both the Red River and Ratcliffe. A vertical well in the Red River will test attribute analysis of 3D seismic data for prediction of porosity development. Additional seismic acquisitions and interpretation are in progress for both the Ratcliffe and Red River. A water-injectivity test in a new horizontal completion in the Red River B zone at Buffalo Field is scheduled for next quarter. 


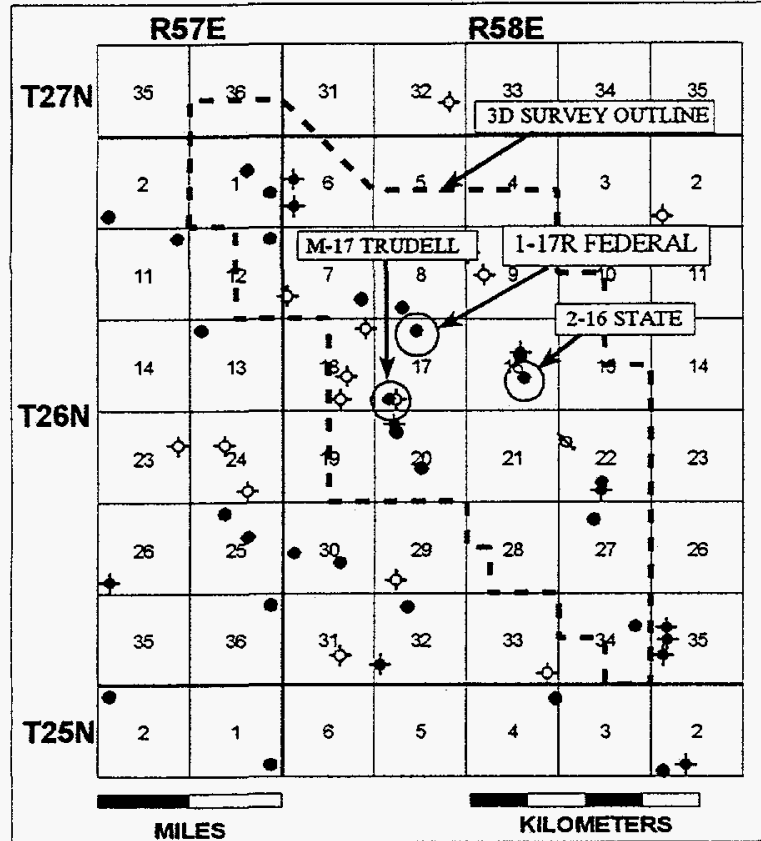

Figure 1: Map of North Sioux Pass Field, Richland Co., MT.
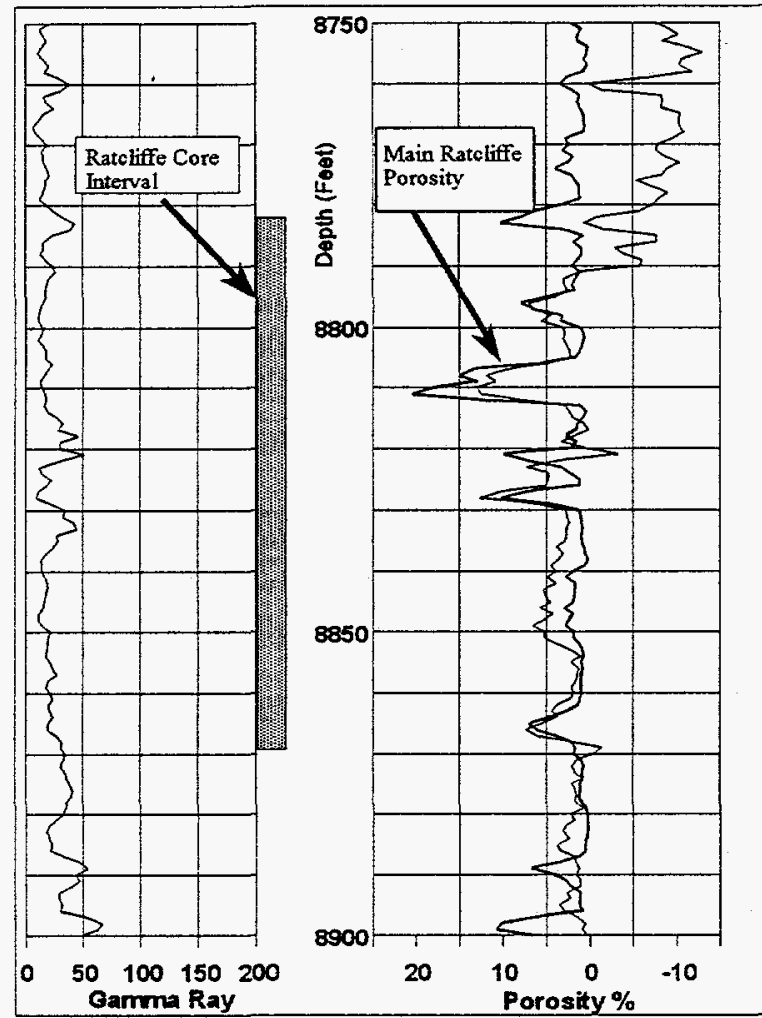

Figure 2: Porosity log across the Ratcliffe interval from 1-17R Federal, North Sioux Pass Field.

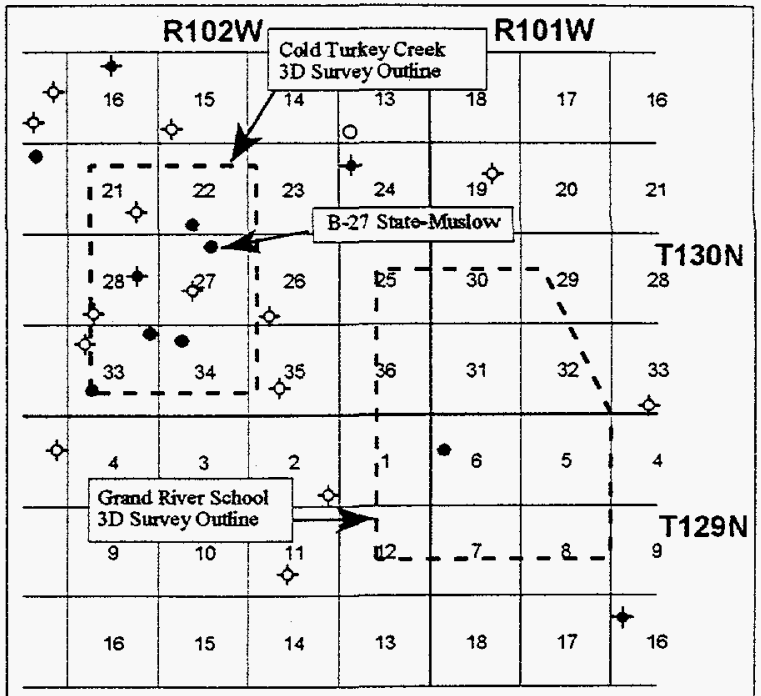

Figure 3: Map of Cold Turkey Creek and Grand River School Fields, Bowman Co., ND.

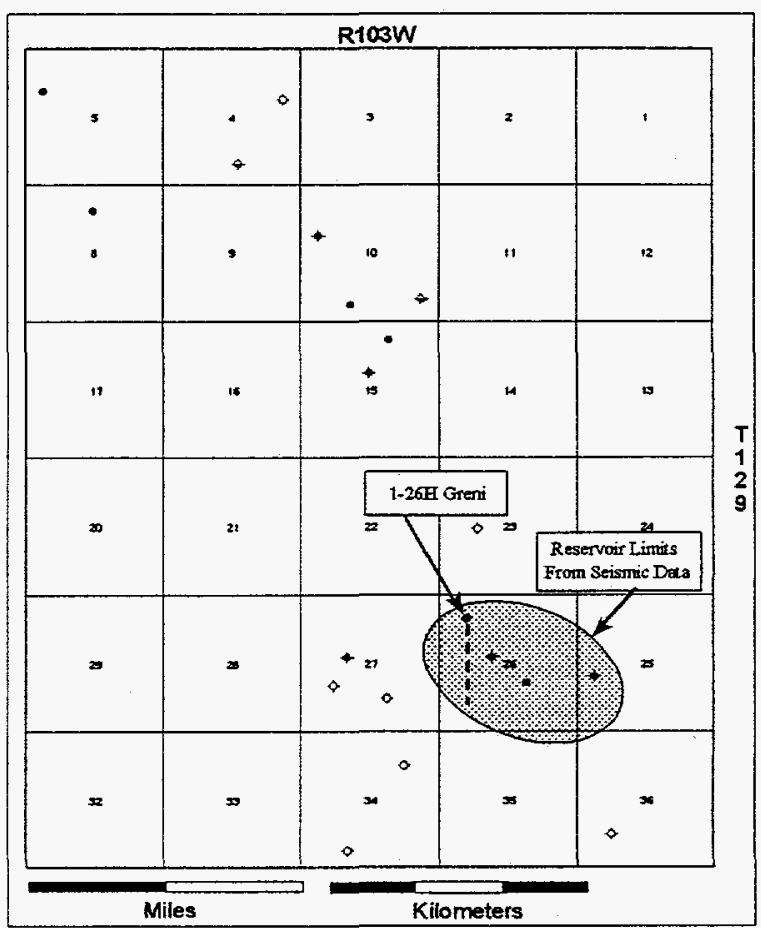

Figure 4: Map of State Line Field, Bowman Co., ND. 


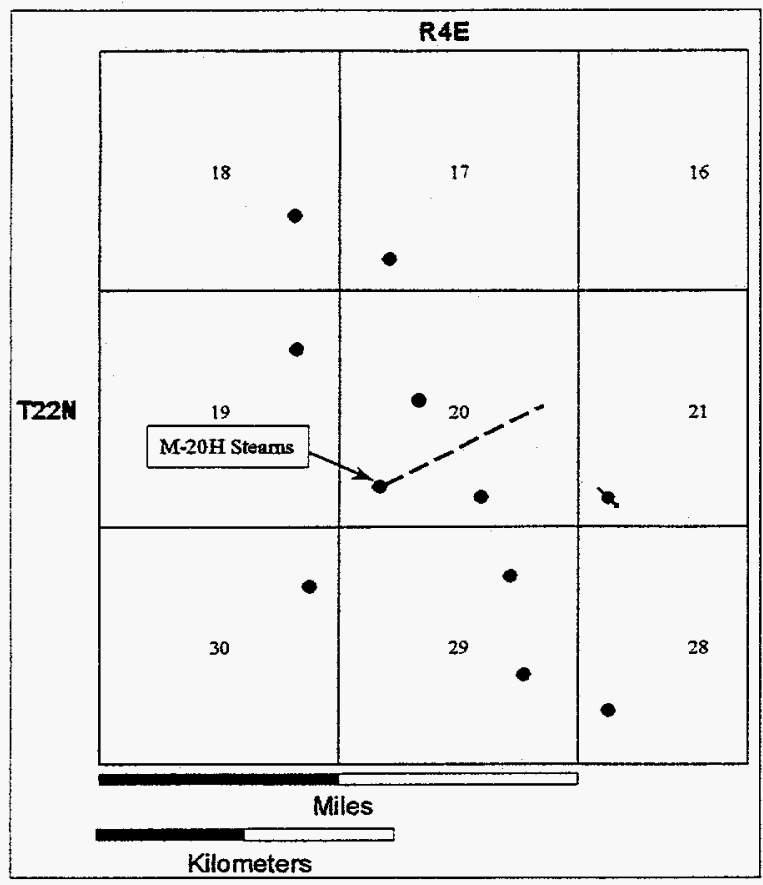

Figure 5: Map of Buffalo Field (north area), Harding Co., SD. 